\title{
Lotteries as Disguised, Regressive, and Counterproductive Taxes
}

\author{
Rick Wolff
}

Published online: 9 March 2010

(C) Springer Science+Business Media, LLC 2010

Lotteries are now operated by most of the 50 United States of America. Because of recent decades of widespread tax revolts, state politicians have had to find disguises for-or new masked forms of - taxation. With determination and heavy promotion, they have succeeded in largely reversing the older American notion that gambling is sinful. In the elegant words of conservative South Carolina State Senator Robert Ford, reported by the Associated Press, "Gambling ain't no blight on society." Far from sinful, lottery ticket purchases have instead become socially approved ways of "supporting our state's schools" and "enjoying very human fantasies" of quick wealth.

States have generated significant new revenues by means of lotteries and anticipate more in the future even as other state tax revenues are decreasing. Nor is there yet much concern that the major buyers of lottery tickets are those at the lower end of the income distribution. As a means of raising states' revenues, lotteries are regressive: the percentage of one's income spent on them rises as one's income falls.

\footnotetext{
R. Wolff $(\bowtie)$

University of Massachusetts, Amherst, MA, USA

e-mail: rdwolff@att.net
}

Present Address:

R. Wolff

Graduate Program in International Affairs, New School University, New York City, NY, USA 
Consider the rising importance of state lottery revenues also documented in that Associated Press story:

\section{Betting on state gambling}

States rely on revenue from different gambling sources as a key element in overall revenues, and often consider expansion of such activities during economic downturns.

\section{State gambling revenue (Total U.S.)}

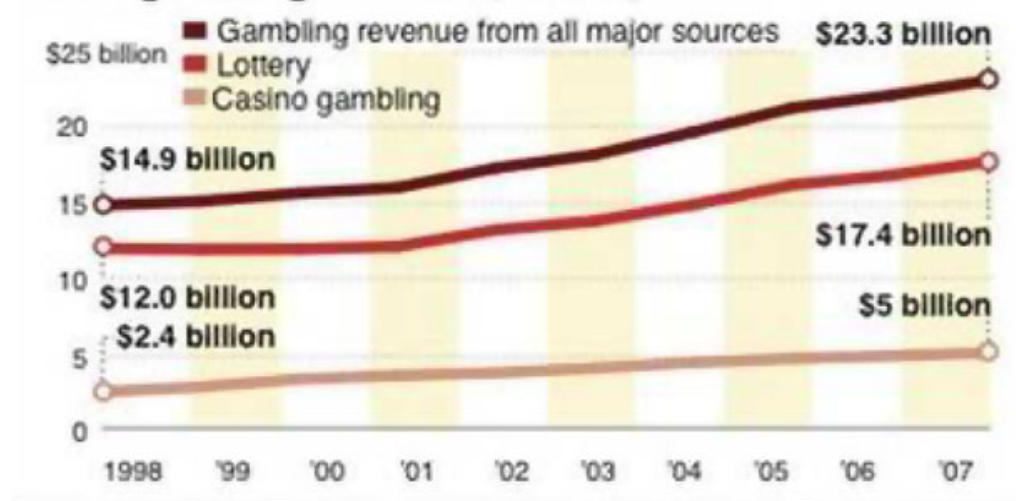

SOURCES: U.S. Census Bureau, Rockofoller Institute

AP

Both Republicans and Democrats have been moving steadily toward ever more lottery ticket sales; there is no reason to doubt that they will continue.

Where exactly do lottery revenues come from? A famous recent study by Cornell University researchers (Blalock et al. 2004) reached these conclusions:

... lotteries are extremely popular, particularly among low income citizens. . . . [I] ndividuals with lower incomes substitute lottery play for other entertainment. . . . [L] ow income consumers may view lotteries as a convenient and otherwise rare opportunity for radically improving their standard of living. . . . [T] he desperate may turn to lotteries in an effort to escape hardship. We . . . find a strong and positive relationship between sales and poverty rates. . .

In another study, Duke University researchers in 1999 (Clotfelter et al. 1999) found that the more education one has the less one spends on lottery tickets: dropouts averaged $\$ 700$ annually compared to college graduate's $\$ 178$; and that those from households with annual incomes below $\$ 25,000$ spent an average of nearly $\$ 600$ per year on lottery tickets, while those from households earning over $\$ 100,000$ averaged $\$ 289$; blacks spent an average of \$998, while whites spent \$210.

Put simply, lotteries take the most from those who can least afford it. Thus, still another study of state lotteries concluded: "We find that the implicit tax is regressive in virtually all cases." (Clotfelter and Cook 1988) Instead of taxing those most able to pay (the principle of the federal income tax in the US), state leaders use lotteries to disguise a regressive tax that falls on the middle and even more on the poor.

The states' usages of their lottery revenues are well known. Some $50-70 \%$ go to the winners; $20-40 \%$ go to pay for states' public services (often education) and the rest (10- 
$20 \%$ ) go for "expenses" of running lotteries. In 2006, over half of California's lottery receipts used for these "expenses" were paid as commissions to retailers for selling lottery tickets. Sales per retail outlet in 2006 averaged $\$ 188,000$ in California (and \$405,000 in New York). For many retailers across the country, profits from the fully automated selling of lottery tickets significantly boost their bottom lines; for some, revenues from lottery ticket sales keep them from bankruptcy.

Lotteries function as mechanisms to redistribute wealth from the poorer to the richer. The vast majority of middle-income and poor people buy tickets and win nothing or nearly nothing, while a tiny number of winners become wealthy. Lotteries raise ever more money for states from their middle-income and poor citizens rather than from those most able to pay. The richer escape the disguised taxation of lotteries by not buying the tickets. Retail merchants gain profitable commissions on their virtually costless lottery ticket sales. Politicians boast that they "did not raise taxes"- having raised money instead by lottery ticket sales.

The effects of lotteries in today's economic crisis are even more perverse. Lotteries take huge sums from masses of middle-income and poor people who would otherwise have spent all that money on goods and services whose production would have provided jobs for others. The lotteries then distribute over half of their revenues from ticket sales to a few, suddenly very rich individuals who will not spend all that money. The net result is less money spent and fewer jobs created. This is the exact opposite of the kind of economic stimulus a depressed economy needs. Yet many states are now planning increases in lottery sales to raise money to offset lost tax revenues because of high unemployment.

Lotteries are also powerful ideological and political weapons. They reinforce notions that individual acts-buying lottery tickets-are appropriate responses to society's economic problems. Lotteries help to distract people from collective action to solve the economic crisis by changing society. Lotteries' massive advertising shows an audacity of hype: shifting people from hope for social change produced by collective action to hope for personal gain by individual gambling.

Finally, compare lotteries (disguised taxes) with taxes that do not wear masks. Taxes raise money that mostly goes to fund states' provision of public services. Lottery revenues make a few winners wealthy at the expense of the mass of taxpayers; only small portions of lottery revenues fund states' services. Society can target taxes to tap those most able to pay (something done partially by the US federal income tax); that is not done by lotteries. Taxes can enable the states to provide public education, child and elderly care, public transportation and so on without devoting scarce state funds to pay for state employees and state-funded advertising that push people to gamble more, which is what lotteries do.

The issue here is not gambling per se; the point is not to engage the religious, moral, or mental health debates over gambling. Rather, what matters is the cynical use of state lotteries to disguise unfair tax burdens even as they worsen the economic crisis.

Are there fairer, better ways than lotteries to help the states' strained revenue situations? Indeed. One alternative to lotteries would be a property tax levied on stocks and bonds. In the United States, only some forms of property are already taxed, chiefly at the local, municipal level: land, homes, commercial and industrial buildings, automobiles, and business inventories. Stocks and bonds are exempted from the property tax. Stocks and bonds are the forms in which the richest citizens hold most of their property. A property tax on stocks and bonds - levied on a national basis to avoid differential rates among the statescould easily raise far more than lotteries do, tax those most able to pay, and thereby end the injustice of allowing owners of stocks and bonds to avoid the taxes now levied on the other sorts of property most citizens own (cars, homes, etc.). 


\section{References}

Blalock, G., Just, D. R., \& Simon, D. H. (2004). Hitting the jackpot or hitting the skids: Entertainment, poverty, and the demand for state lotteries http://aem.cornell.edu/faculty_sites/gb78/wp/lottery.pdf.

Clotfelter, C. T., \& Cook, P. J. (1988). Implicit taxation in lottery finance. NBER Working Paper No. W2246 http://papers.ssrn.com/sol3/papers.cfm?abstract_id=347029.

Clotfelter, C. T., Cook, P. J., Edell, J. A., \& Moore, M. (1999). State lotteries at the turn of the century: Report to the national gambling impact study commission http://govinfo.library.unt.edu/ngisc/reports/ lotfinal.pdf. 